\title{
How to Restore Equitable and Sustainable Economic Growth in the United States
}

\author{
By Joseph E. Stiglitz*
}

While we celebrate the beginning of the end of the era of zero interest rates, the US economy can hardly be called healthy. GDP is some 15 percent below what it would have been had the growth rates that prevailed between 1980 and 1998 continued. The percentage of the working-age population employed has increased only slightly since the "recovery" began, and is still lower than it was in the early 1980s, when women were entering the workforce en masse. ${ }^{1}$ Median real (household) income is less than 1 percent higher than it was in $1989 .{ }^{2}$ Real wages at the bottom are lower than 60 years ago. ${ }^{3}$ More than a fifth of African American youth are unemployed. ${ }^{4}$ All of this, eight years after the beginning of the last recession.

The underlying problem is a lack of aggregate demand, but there are some related and

* Columbia University, Uris Hall, 3022 Broadway, Room 212, New York, NY 10027 (e-mail: Jes322@ columbia.edu). Paper presented to the American Economic Association, San Francisco, January 3, 2016. Financial support of INET (the Institute for New Economic Thinking) and the Ford Foundation Inequality Project at Roosevelt Institute, supported by the Ford and MacArthur Foundations and the Bernard and Irene Schwartz Foundation, is gratefully acknowledged, as is research assistance from Debarati Ghosh and Eamon Kircher-Allen.

${ }^{\dagger}$ Go to http://dx.doi.org/10.1257/aer.p20161006 to visit the article page for additional materials and author disclosure statement.

${ }^{1}$ See the St. Louis Fed's presentation of Bureau of Labor Statistics data, https://research.stlouisfed.org/fred2/series/ EMRATIO.

${ }^{2}$ Census Historical Income Table H-6, https://www.census. gov/hhes/www/income/data/historical/household/2014/ h06AR.xls.

${ }^{3}$ Minimum wages (adjusted for inflation) were some 24 percent lower than they were in 1968 . Real wages at the tenth percentile are below what they were in 1980, while those at the thirtieth percentile have barely increased. See Gould (2014).

${ }^{4}$ The unemployment rate for African Americans aged 16-24 was 20.7 percent in July 2015, the last month for which the Bureau of Labor Statistics reported that data, http://www.bls.gov/news.release/empsit.t02.htm. fundamental supply-side problems. Think about where the economy was in 2007: while aggregate demand and supply were roughly in balance, demand was supported by an unsustainable housing bubble. The bottom 80 percent were spending 110 percent of their income. It was inevitable that the (personal) savings rate would increase from its record 2005 low of 1.9 percent; even now, at 5.4 percent, it is below what one would think of as a normal, sustainable level. ${ }^{5}$ Meanwhile, America has been experiencing its own mild form of austerity, with public sector employment some 500,000 below 2008, while with normal expansion, in line with the growth of the population, it would have been more than two million higher. ${ }^{6}$ A weak global economygrowth in 2015 was slated to be the weakest of any year this century, save the recessions of 2001-2002 and 2008-20097 — and a strong and strengthening dollar do not bode well for exports. With $C, X$, and $G$ weak, it's perhaps not a surprise that so is investment. Globally, the flood of money from monetary easing, including QE, has not led to the hoped for increase in investment.

\section{Misdiagnosis of the Great Recession}

Eight years ago there was a misdiagnosis of the recession. Some thought it was a financial crisis: the banks had been reckless in lending. They needed to be recapitalized and reformed. That has largely happened: Dodd-Frank, though far from perfect, was at least a start; and bank balance sheets have largely been restored. Still, the economy remains weak.

\footnotetext{
${ }^{5}$ Bureau of Economic Analysis data as reported by the St. Louis Fed, https://research.stlouisfed.org/fred2/series/ PSAVERT.

${ }^{6}$ Based on Bureau of Labor Statistics data, http://data.bls. gov/timeseries/CES9000000001.

${ }^{7}$ IMF World Economic Outlook, October 2015, https:// www.imf.org/external/pubs/ft/weo/2015/02/pdf/text.pdf.
} 
Partly, this is because the Fed and administration focused on the big systemically significant banks, not on local, community, and regional banks which are disproportionately responsible for small and medium enterprise (SME) lending. While no one such bank alone may be systemically significant, in the aggregate, reduced lending to SME is systemically significant. Focusing more on repairing the credit channel would have meant that more of the increased liquidity went to increase investment rather than to increasing prices of existing assets, creating asset bubbles.

Some thought the downturn was a balance sheet recession; and again, the recovery from such recessions is slow, because balance sheets recover slowly. Balance sheets were hurt, but this downturn was more than a balance sheet recession. The balance sheets of large corporations are sufficiently good that dividends and CEO pay are robust. These corporations earn large fractions of their income abroad, and until rather recently, emerging market growth has been strong. Large American corporations are sitting on almost two trillion dollars of cash. It is not corporate balance sheets or their access to finance that are holding them back from investing: it is lack of demand.

\section{A. Underlying Problems}

There are at least five related underlying problems. The first is inequality. The increase in inequality has weakened consumption from what it otherwise would be. Those at the top spend a smaller percentage of their income than the rest.

The second is structural transformation: the United States has been moving from a manufacturing to a service sector economy. Global manufacturing employment is in the decline, and with globalization, the United States will be seizing a declining share of that employment, specializing in skill- and capital-intensive niches. For a while, construction masked what was going on; but the real estate bubble was but a short-term palliative. Among the service sectors that should be taking up the slack are education and health. In both, government rightly plays an important role, and austerity has constrained the ability of the government to play the role which it should. More generally, for understandable reasons related to capital market imperfections, markets on their own do a poor job at managing the kind of large structural transformation that is needed. 8

These structural changes pose several challenges. The new economy may be less capital-intensive, so that the investment needed to support a given growth in GDP may be smaller. Older workers especially may be ill-prepared for the new economy. With the aging of the baby boomers, a larger fraction of workers are older; the societal costs of not retooling-of simply accepting their obsolescence-are higher.

The third is the financial sector. Reform discussions have focused on preventing the sector from imposing harm on the rest of society-preventing negative externalities. Little attention has been paid to ensuring that the sector fulfills the important societal roles that it needs to fulfill if the economy is to function well, e.g., providing SME and housing finance, managing retirement accounts, and running the payments system at low transactions cost. Almost a decade after the breaking of the housing bubble, almost all mortgages continue to be underwritten by the government.

The fourth is underinvestment by government in infrastructure and technology, both of which are complementary to private capital. With government support of basic research (as a percentage of GDP) lower than it was a half century ago, ${ }^{9}$ the wellspring of ideas driving new innovations to increase productivity may be drying up.

The final is political: continuing austerity, in the presence of inadequate private demand, and in the face of the other problems I have delineated, effectively ensures an underperforming economy.

\section{Restoring Shared Prosperity}

The solutions to the economy's doldrums, alternatively referred to as the Great Malaise and the New Mediocre, follow directly from the diagnosis. In the discussion below, I put aside questions of political feasibility. Two policies that are not likely to work are monetary policy and new trade agreements. They may in fact exacerbate the economy's problems.

\footnotetext{
${ }^{8}$ See Delli Gatti et al. (2012).

${ }^{9}$ Though higher than it was in 1975 . From the National Science Foundation, http://www.nsf.gov/statistics/2015/ nsf15324/pdf/tab1.pdf, and the Bureau of Labor Statistics.
} 
Monetary Policy.-Monetary policy alone has proven insufficient to restore growth; indeed, recent policies have arguably increased inequality (Stiglitz 2015a). Low interest rates encourage the use of relatively capital intensive technology, making a "jobless" recovery more likely. I don't believe the zero lower bound (ZLB) explains the limitations on the efficacy of monetary policy; but with monetary policy moving off the ZLB, this will no longer be an excuse. (For those who continue to focus on intertemporal prices, consumption taxes increasing over time combined with investment tax credits decreasing over time can circumvent the limitations of the ZLB.)

Trade Agreements.-Proposed trade agreements may make matters worse: the United States imports labor-intensive goods, and exports capital-intensive goods, so that any reasonably balanced trade agreement will reduce employment. Moreover, investment provisions which reduce the risk of investing abroad encourage shifting production abroad.

There is, however, an agenda that will work to restore growth:

Climate Change.--Imposing a carbon price, reflecting the social cost of emissions, would significantly stimulate investment. To ensure a level playing field, we might have to impose cross-border adjustments. A carbon tax would simultaneously raise substantial revenues needed to finance the public investments described elsewhere in this paper.

Infrastructure and Technology.-With the real interest rate at which government can borrow much lower than the returns on public investments in infrastructure and technology, such investments would increase growth both today and in the future. And since much of this public investment is complementary with private capital, private investment will be stimulated, providing a further spur to the economy. Institutionally, this investment could be financed through an infrastructure bank: the European Investment Bank has proven to be an effective way of financing cost-effective infrastructure on a large scale.

Ending Austerity.-The notions of expansionary contractions (Alesina and Ardagna 2010) and that there is a critical threshold above which debt lowers growth have been discredited (IMF 2010; Baker 2010; Jayadev and Konczal 2010; Herndon, Ash, and Pollin 2014). Austerity hurts now, and in the future: hysteresis effects mean even potential growth is lowered (Reifschneider, Wascher, and Wilcox 2013). If fiscal deficits are a concern, the balanced budget multiplier means that increasing taxes in tandem with investment spending increases GDP now and in the future.

Fighting Inequality.-The country's high and growing inequality is not just the result of ordinary shifts in supply and demand curves in competitive markets, such as those brought on by changes in technology and globalization. Rather, growing inequality is largely the result of changes in the rules of the game and the way they are implemented. Markets don't exist in a vacuum, and the way they are structured affects how they function, market efficiency, and distribution (Stiglitz et al. 2015). Increases in rents can help explain the anomaly of an increased wealth/income ratio accompanied by a decrease in the ratio of productive capital to income, as well as some of the marked changes in distribution (Stiglitz 2015c). The rules can and should be rewritten, in ways that promote equality, growth, and employment and reduce exclusion. For instance, taxes on rents (both those associated with land and natural resources) would increase investment in productive assets and again provide substantial revenues. Rewriting the rules would address the marked disparity between the growth in labor productivity and real wages that has opened up during the past third of a century. Eliminating the preferential treatment of capital gains - especially on land - and other forms of return on capital would reduce another set of distortions in the economy, increase the overall progressivity of the tax system, reduce inequality, and generate substantial revenues (Stiglitz 2015b).

Reduced inequality itself would improve economic performance, not just in the short term, but also in the long (Stiglitz 2012; Ostry, Berg, and Tsangarides 2014).

Reforming the Financial Sector.-Among other reforms that are needed and could be accomplished by rewriting the rules are those that shape the financial sector. Sitting between long-term savers and long-term investment needs are short-sighted financial markets, which 
have been more active in disintermediating corporations than in intermediating between savers and investors. Reducing financial sector induced distortions in the allocation of human and physical capital would also contribute to long-term growth.

Structural Transformation.-More than a half century ago, our economy needed to make another structural transformation, from agricultural to manufacturing (Delli Gatti et al. 2012). The market failed to manage this transformation smoothly. Costly mobility trapped labor in the agricultural sector. It was government action, through spending during and after World War II (including through the GI bill), that brought about the transition. Once again, the government needs to take an active role, including through more active labor market policies. Such policies only work, however, if there are jobs for the retrained workers. The policies described above will help ensure that these are created.

Reforming Global Financial Architecture.The global context is, however, markedly different today than it was 70 years ago. While, as I explained above, the proposed trade agreements may be counterproductive, reforms in the global financial system could help. The role of the dollar as the reserve currency is not only an anachronism, but leads to a stronger dollar, impeding exports. A global reserve system, as suggested by Keynes and a recent UN Commission that I chaired, would lead to greater global stability and a stronger American economy (Greenwald and Stiglitz 2010; Stiglitz and UN 2010).

\section{Concluding Remark}

The malaise in which the country has been for eight years is likely to continue unless something changes. This paper has outlined an agenda that would enable us to restore robust equitable and sustainable growth.

\section{REFERENCES}

Alesina, Alberto, and Silvia Ardagna. 2010. "Large Changes in Fiscal Policy: Taxes versus Spending." In Tax Policy and the Economy, Vol. 24, edited by Jeffrey R. Brown, 35-68.
Cambridge, MA: National Bureau of Economic Research Books.

Baker, Dean. 2010. "The Myth of Expansionary Fiscal Austerity." Center for Economic and Policy Research Issue Brief.

Delli Gatti, Domenico, Mauro Gallegati, Bruce C. Greenwald, Alberto Russo, and Joseph E. Stiglitz. 2012. "Mobility Constraints, Productivity Trends, and Extended Crises." Journal of Economic Behavior and Organization 83 (3): 375-93.

Greenwald, B., and J. E. Stiglitz. 2010. "A Modest Proposal for International Monetary Reform." In Time for a Visible Hand: Lessons from the 2008 World Financial Crisis, edited by S. Griffith-Jones, J. A. Ocampo, and J. E. Stiglitz, 314-44. Oxford, UK: Oxford University Press.

Gould, Elise. 2014. "Why America's Workers Need Faster Wage Growth - and What We Can Do About It." Economic Policy Institute Briefing Paper 382, August 27, 2014.

Herndon, Thomas, Michael Ash, and Robert Pollin. 2014. "Does High Public Debt Consistently Stifle Economic Growth? A Critique of Reinhart and Rogoff." Cambridge Journal of Economics 38 (2): 257-79.

International Monetary Fund. 2010. "Will It Hurt? Macroeconomic Effects of Fiscal Consolidation." In World Economic Outlook: Recovery Risk and Rebalancing, 93-124. Washington, DC: International Monetary Fund Publication Services.

-Jayadev, Arjun, and Mike Konczal. 2010. "When Is Austerity Right? In Boom, Not Bust." Challenge 53 (6): 37-53.

Ostry, J. D., A. Berg, and C. G. Tsangarides. 2014. "Redistribution, Inequality, and Growth." International Monetary Fund Staff Discussion Note SDN/14/02.

Reifschneider, Dave, William Wascher, and David Wilcox. 2013. "Aggregate Supply in the United States: Recent Developments and Implications for the Conduct of Monetary Policy." Paper presented at the $14^{\text {th }}$ Jacques Polak Annual Research Conference, Washington, DC.

Stiglitz, Joseph E. 2012. The Price of Inequality. New York: W.W. Norton.

Stiglitz, Joseph E. 2015a. "Fed policy, Inequality, and Equality of Opportunity." Paper presented at the Ninth Biennial Federal Reserve System Community Development Research Conference, Washington, DC. 
Stiglitz, Joseph E. 2015b. "The Origins of Inequality, and Policies to Contain It." National Tax Journal 68 (2): 425-48.

Stiglitz, Joseph E. 2015c. "New Theoretical Perspectives on the Distribution of Income and Wealth Among Individuals: Parts I-IV." National Bureau of Economic Research Working Paper 21189-21192.

Stiglitz, Joseph E., N. Abernathy, A. Hersh, S.
Holmberg, and M. Konczal. 2015. Rewriting the Rules of the American Economy. New York: W.W. Norton.

Stiglitz, Joseph E., and Members of a UN Commission of Financial Experts. 2010. The Stiglitz Report: Reforming the International Monetary and Financial Systems in the Wake of the Global Crisis. New York: The New Press. 
This article has been cited by:

1. J.E. Stiglitz. 2016. An Agenda for Sustainable and Inclusive Growth for Emerging Markets. Journal of Policy Modeling . [CrossRef] 